WMJ (Warmadewa Medical Journal), Vol. 5 No. 1 Mei 2020, Hal. 22-29

\title{
Case-Control Research on Hypertension Risk Factors in Karangasem Village, Karangasem Regency, Bali
}

\author{
I Wayan Satwika Adhikara ${ }^{1}$, Anak Agung Gede Budhitresna ${ }^{2}$ \\ ${ }^{1}$ Medical Education Program, Faculty of Medicine and Health Sciences, Warmadewa University, Denpasar \\ ${ }^{2}$ Department of Internal Medicine, Faculty of Medicine and Health Sciences, Warmadewa University, \\ Denpasar \\ Email': Indo.pusaka@yahoo.co.id
}

\begin{abstract}
Hypertension is still a health problem globally. Several studies have been conducted to find the relationship between risk factors with the incidence of hypertension. There is no data yet on risk factors for hypertension in the community, especially in Karangasem Regency, Bali. This study aims to find the correlation of various risk factors with the incidence of hypertension in Karangasem Regency, Bali. A casecontrol studies was conducted on 100 subjects. Cases and controls were selected using consecutive sampling technique. Logistic regression was used to predict various risk factors for hypertension. The results showed a significant relationship with age $(\mathrm{OR}=2,452 ; \mathrm{p}=0.047 ; 95 \% \mathrm{CI}=0.999-6.018)$, family history $(\mathrm{OR}=4,373$; $\mathrm{p}=0.001 ; 95 \% \mathrm{CI}=1,854-10,316), \mathrm{BMI}(\mathrm{OR}=3,341 ; \mathrm{p}=0.004 ; 95 \% \mathrm{CI}=1,440-7,753)$, smoking $(\mathrm{OR}=$ $2,698 ; p=0.021 ; 95 \% C I=1,148-6,341)$, high salt consumption $(\mathrm{OR}=2,571 ; \mathrm{p}=0.024 ; 95 \% \mathrm{CI}=1,122-$ $5,895)$ and coffee consumption $(\mathrm{OR}=3,451 ; \mathrm{p}=0.016 ; 95 \% \mathrm{CI}=1,220-9,759)$, while no significant relationship was found between sexes $(\mathrm{OR}=0.712 ; \mathrm{p}=0.476 ; 95 \% \mathrm{CI}=0.279-1,818)$, and alcohol consumption $(\mathrm{OR}=0.786 ; \mathrm{p}=0.548 ; 95 \% \mathrm{CI}=0.358-1.725)$. We found an association between several risk factors (age, family history, BMI, smoking, high salt consumption, and coffee consumption) and the incidence of hypertension in the Karangasem Village, Karangasem Regency, Bali.
\end{abstract}

Keywords: risk factors, hypertension, Karangasem village

\author{
Abstrak \\ [Penelitian Kasus-Kontrol Faktor-Faktor Risiko Hipertensi di Desa Karangasem Kabupaten Karangasem \\ Provinsi Bali]
}

Secara global hipertensi masih merupakan masalah kesehatan di masyarakat. Beberapa penelitian telah dilakukan untuk mencari hubungan antara beberapa faktor risiko dengan kejadian hipertensi. Belum ada data mengenai faktor-faktor risiko kejadian hipertensi di masyarakat, khususnya di Kabupaten Karangasem Bali. Penelitian ini bertujuan untuk mencari hubungan berbagai faktor risiko dengan kejadian hipertensi di masyarakat Kabupaten Karangasem Bali.Penelitian kasus-kontrol dilakukan pada 100 subyek, dimana antara kasus dan kontrol dipilih menggunakan teknik non-random sampling yaitu consecutive sampling. Regresi logistik dipergunakan untuk memprediksi berbagai faktor risiko dengan kejadian hipertensi. Hasil penelitian menunjukkan adanya hubungan bermakna antara usia $(O R=2,452 ; p=0,047 ; 95 \% C I=0,999-6,018)$, riwayat keluarga $(O R=4,373 ; p=0,001 ; 95 \% C I=1,854-10,316), \quad I M T(O R=3,341 ; \quad p=0,004 ; 95 \%$; $C I=1,440-7,753$, merokok $(O R=2,698 ; p=0,021 ; 95 \% ; C I=1,148-6,341)$, konsumsi tinggi garam $(O R=2,571 ; p=0,024 ; 95 \%$; $C I=1,122-5,895)$ dan konsumsi kopi $(O R=3,451 ; p=0,016 ; 95 \% ; C I=1,220-9,759)$ dengan kejadian hipertensi. Tidak didapatkan hubungan secara bermakna antara jenis kelamin $(O R=0,712 ; p=0,476 ; 95 \%$; $C I=0,279-1,818)$ dan konsumsi alkohol $(O R=0,786 ; p=0,548 ; 95 \% ; \quad C I=0,358-1,725)$ dengan kejadian hipertensi. Didapatkan hubungan antara faktor risiko usia, riwayat keluarga, IMT, merokok, konsumsi tinggi garam, dan konsumsi kopi terhadap kejadian hipertensidi masyarakat Desa Karangasem Kabupaten Karangasem Bali.

Kata Kunci: faktor risiko, hipertensi, desa karangasem 


\section{BACKGROUND}

Hypertension is a clinical condition characterized by an increase in blood pressure of 140/90 $\mathrm{mmHg}$. Its increasing prevalence makes hypertension as one of the major public health problems globally. ${ }^{1.2}$ According to the American Heart Association (AHA), the Seventh Report of the Joint National Committee VII (JNC 7), and the World Health Organization (WHO), hypertension is the cause of death around $45 \%$ patients with coronary heart disease and $51 \%$ of patients with stroke. ${ }^{3.4}$ Another report showed that $20 \mathrm{mmHg}$ increase in blood pressure systolic or $10 \mathrm{mmHg}$ in diastolic would increase the risk of stroke and cardiovascular diseases. ${ }^{5}$ Hypertension occurs in almost all populations throughout the world. The National Health and Nutrition Examination Survey (NHANES) in the United States reports about $30 \%$ of the adult population or 65 million people suffering from hypertension. Besides, the incidence of hypertension increases in line with age as $65.4 \%$ of the population, $>60$ years old, have hypertension. ${ }^{6}$

There are several risk factors for hypertension in the community such as gender, high-salt diet, family history, alcohol consumption, coffee consumption, obesity, and smoking. ${ }^{6}$ In Indonesia, the risk factors of hypertension are significantly associated with the conditions and circumstances of social and economic conditions in the community. The prevalence of hypertension is higher in people with high socio-economic conditions. According to the data of Indonesia Basic Health Research (RISKESDAS) in 2013, the prevalence of hypertension was $26.5 \% .{ }^{7}$ Meanwhile, Bali had $19.9 \%$ of the prevalence, while $24.4 \%$ of all cases were in $\mathrm{Ka}$ rangasem regency. ${ }^{8}$

There are no data on risk factors for the high incidence of hypertension in the $\mathrm{Ka}$ rangasem Regency with low socioeconomic status.

\section{METHODS}

A case-control study was conducted in Karangasem Village, Karangasem Subdistrict, Karangasem Regen- cy, Bali Province between November and December 2016. The research subjects were patients with hypertension which met the inclusion and exclusion criteria from affordable samples selected with consecutive sampling techniques. Selected subjects were those who agreed and signed the informed consent after obtaining ethical clearance approval to conduct the study. Anthropometrics status including height and weight were measured and body mass index (BMI) was calculated by dividing body weight in $\mathrm{kg}$ with height in $\mathrm{m}^{2}$. The diagnosis of hypertension was made by using criteria from JNC 7. Cases are individuals with hypertension who meet the inclusion and exclusion criteria, while controls are individuals without hypertension who had been selected from individuals around the cases without family relationships.

All subjects were interviewed using interview guidance instruments which included a family history of hypertension, smoking, alcohol consumption, coffee consumption, salt consumption, physical examination, anthropometry, and demographic status. Blood pressure was checked 3 times in a sitting position after a 5minute break. Systolic and diastolic blood pressure is determined based on the mean values of the three examinations. Subjects were said to have hypertension if their blood pressure was $\geq 140 / 90 \mathrm{mmHg}$. Secondary data were collected to determine the history and status of hypertensive subjects.

Blood pressure was examined using the sphygmomanometer (Reister) and body weight was measured using a scale (Camry) with a deviation level of $100 \mathrm{~g}$ $(0.2 \mathrm{lb})$. Height was measured using the meter scale (Onemed) with prior calibration.

Baseline data characteristics between cases and controls were presented using mean and standard deviation. Statistical Package for Social Science (SPSS) version 15.0 was used to do the statistical analysis. The group average was compared using paired student's t-test which was then followed by post-hoc analysis. Homogeneity and normality of variance were checked by 


\section{WMJ (Warmadewa Medical Journal), Vol. 5 No. 1, Mei 2020, Hal. 24}

using the Levene test and the KosmogorovSmirnov test, respectively. The correlation coefficient between hypertension and various parameters was calculated using Pearson's correlation test. Logistic regression analysis was used to measure odds ratios and confidence intervals (CI) of $95 \%$ as an estimate of the relative risk of hypertension. A statistically significant level of $\mathrm{p}$ $<0.005$ was used.

\section{RESULTS}

The characteristics of the subjects involved in this study, both as cases and controls are shown in Table 1. Data, as presented in Table 1, are mostly normally distributed after being tested using the Kosmogorov-Smirnov test at a significance level of $5 \%$.

Table 1. Basic characteristics of the research subjects

\begin{tabular}{|c|c|c|c|}
\hline & & $\begin{array}{c}\text { Cases }(n==50) \\
\text { Mean } \pm \text { SD }\end{array}$ & $\begin{array}{c}\text { Controls }(n=50) \\
\text { Mean } \pm \text { SD }\end{array}$ \\
\hline \multicolumn{4}{|l|}{ Gender } \\
\hline & Male & $37(48,1 \%)$ & $40(51,9 \%)$ \\
\hline & Female & $13(56,5 \%)$ & $10(43,5 \%)$ \\
\hline \multicolumn{4}{|l|}{ Age } \\
\hline & $<64$ years & $31(43,7 \%)$ & $40(56,3 \%)$ \\
\hline & $\geq 64$ years & $19(65,5 \%)$ & $10(34,5 \%)$ \\
\hline \multicolumn{4}{|c|}{ Education Level } \\
\hline & None & $13(72,2 \%)$ & $5(27,8 \%)$ \\
\hline & Elementary School & $11(50,0 \%)$ & $11(50,0 \%)$ \\
\hline & Junior High School & $4(40,0 \%)$ & $6(60,0 \%)$ \\
\hline & Senior High School & $16(43,2 \%)$ & $21(56,8 \%)$ \\
\hline & University & $6(46,2 \%)$ & $7(53,8 \%)$ \\
\hline \multicolumn{4}{|c|}{ Occupancy } \\
\hline & Housewife & $4(50,0 \%)$ & $4(50,0 \%)$ \\
\hline & Civil servant & $6(40,0 \%)$ & $9(60,0 \%)$ \\
\hline & Private worker & $2(100,0 \%)$ & $0(0,0 \%)$ \\
\hline & Entrepreneur & $9(41,0 \%)$ & $13(59,0 \%)$ \\
\hline & Labor & $2(50,0 \%)$ & $2(50,0 \%)$ \\
\hline & Others & $27(55,1 \%)$ & $22(44,9 \%)$ \\
\hline
\end{tabular}

Bivariate analysis showed several factors that were found to have a significant effect $(p<0.005)$ on the incidence of hypertension such as age, family history, BMI, smoking habits, salt consumption, and cof- fee consumption. While other risk factors such as gender and alcohol consumption did not affect the incidence of hypertension $(\mathrm{p}>0.005)($ Table 2). 
Table 2. Association several risk factors with hypertension

\begin{tabular}{|c|c|c|c|c|c|}
\hline Variables & $\begin{array}{c}\text { Cases } \\
(n=50)\end{array}$ & $\begin{array}{c}\text { Controls } \\
(n=50)\end{array}$ & OR & $95 \% \mathrm{CI}$ & $\mathbf{p}$ \\
\hline Gender & & & 0,712 & $0,279-1,818$ & 0,476 \\
\hline Male & $37(74,0 \%)$ & $40(80,0 \%)$ & & & \\
\hline Female & $13(26,0 \%)$ & $10(20,0 \%)$ & & & \\
\hline Age & & & 2,452 & $0,999-6,018$ & $0,047 *$ \\
\hline$\geq 64$ years & $19(38,0 \%)$ & $10(10,0 \%)$ & & & \\
\hline$<64$ years & $31(62,0 \%)$ & $40(80,0 \%)$ & & & \\
\hline Family History & & & 4,373 & $1,854-10,316$ & $0,001 *$ \\
\hline Yes & $29(58,0 \%)$ & $12(24,0 \%)$ & & & \\
\hline No & $21(42,0 \%)$ & $38(76,0 \%)$ & & & \\
\hline BMI & & & 3,341 & $1,440-7,753$ & $0,004 *$ \\
\hline$\geq 25 \mathrm{Kg} / \mathrm{m}^{2}$ & $27(54,0 \%)$ & $13(26,0 \%)$ & & & \\
\hline$<25 \mathrm{Kg} / \mathrm{m}^{2}$ & $23(46,0 \%)$ & $37(74,0 \%)$ & & & \\
\hline Smoking & & & 2,698 & $1,148-6,341$ & $0,021 *$ \\
\hline Yes & $38(76,0 \%)$ & $27(54,0 \%)$ & & & \\
\hline No & $12(24,0 \%)$ & $23(46,0 \%)$ & & & \\
\hline Salt Consumption & & & 2,571 & $1,122-5,895$ & $0,024 *$ \\
\hline$\geq 6$ Gram & $36(72,0 \%)$ & $25(50,0 \%)$ & & & \\
\hline < 6 Gram & $14(28,0 \%)$ & $25(50,0 \%)$ & & & \\
\hline Coffee Consumption & & & 3,451 & $1,220-9,759$ & $0,016^{*}$ \\
\hline Yes & $44(88,0 \%)$ & $34(68,0 \%)$ & & & \\
\hline No & $6(12,0 \%)$ & $16(32,0 \%)$ & & & \\
\hline Alcohol Consumption & & & 0,786 & $0,358-1,725$ & 0,548 \\
\hline Yes & $24(48,0 \%)$ & $27(54,0 \%)$ & & & \\
\hline No & $26(52,0 \%)$ & $23(26,0 \%)$ & & & \\
\hline
\end{tabular}

Note: $* \mathrm{p}<0,05$ based on chi-square test.

Subsequently, an analysis was performed using logistic regression to evaluate the relationship between smoking, drinking coffee, and alcohol consumption on the incidence of hypertension (Table 3 ). There was a significant relationship between smoking habits of $\geq 20$ cigarettes with the incidence of hypertension which was
$2.81(95 \%, \mathrm{CI}=1.05-7.49)$, compared with those who smoked $<20$ cigarettes per day. Besides, a significant relationship was found between the habit of drinking $\geq 3$ cups of coffee per day with the occurrence of hypertension, which was $5.2(95 \%, \mathrm{CI}=$ 1.04 - 25.77), compared with subjects who drink $<3$ cups of coffee per day. 
Table 3. Logistic regression of hypertension prevalence based on number of cigarettes, coffee and alcohol consumption

\begin{tabular}{|c|c|c|c|c|c|c|}
\hline Variables & $\begin{array}{c}\text { Cases } \\
(n=50)\end{array}$ & $\begin{array}{c}\text { Controls } \\
(n=50)\end{array}$ & B & $\begin{array}{c}\text { Adjusted } \\
\text { OR }\end{array}$ & $95 \% \mathrm{CI}$ & $\mathbf{p}$ \\
\hline \multicolumn{7}{|l|}{ Number of Cigarettes } \\
\hline$\geq 20$ cigarettes & $19(38,0 \%)$ & $7(14,0 \%)$ & 1,034 & 2,811 & $1,055-7,491$ & $0,039 *$ \\
\hline$<20$ cigarettes & $22(44,0 \%)$ & $20(40,0 \%)$ & $-0,903$ & 0,405 & $0,141-1,166$ & 0,094 \\
\hline None ( 0 cigarettes) & $9(18,0 \%)$ & $23(46,0 \%)$ & 0,00 & 1,00 & Reference & - \\
\hline \multicolumn{7}{|l|}{ Amount of Coffee } \\
\hline$\geq 3$ cups & $28(56,0 \%)$ & $12(24,0 \%)$ & 1,649 & 5,200 & $1,049-25,772$ & $0,044 *$ \\
\hline$<3$ cups & $20(40,0 \%)$ & $25(50,0 \%)$ & $-1,070$ & 0,343 & $0,140-0,840$ & 0,019 \\
\hline None (0 cup) & $2(4,0 \%)$ & $13(26,0 \%)$ & 0,00 & 1,00 & Reference & - \\
\hline \multicolumn{7}{|l|}{ Amount of Alcohol } \\
\hline$\geq 3$ cups & $18(36,0 \%)$ & $21(42,0 \%)$ & $-0,123$ & 0,885 & $0,250-3,128$ & 0,849 \\
\hline$<3$ cups & $6(12,0 \%)$ & $6(12,0 \%)$ & 0,154 & 1,167 & $0,320-4,259$ & 0,816 \\
\hline None ( 0 cup) & $26(52,0 \%)$ & $23(46,0 \%)$ & 0,00 & 1,00 & Reference & - \\
\hline
\end{tabular}

Note: $* \mathrm{p}<0,05$ based on logistic regression test.

\section{DISCUSSION}

Several risk factors are reported to have a significant correlation with the incidence of hypertension in the community in Karangasem village, such as age, family history, BMI, smoking, salt consumption, and coffee consumption.

Age is a risk factor of hypertension in the community that cannot be modified. This is related to the increasing age of an individual which followed by decreasing elasticity of arteries. Besides, increasing age is also in line with decreasing plasma renin causing sodium retention which leads to increase blood pressure. ${ }^{12}$ Kartikasari et al reported that the risk of getting hypertension at the age of 60 years was 11 times greater than the age of less than 60 years. ${ }^{9}$ Anggara and Prayitno reported increasing the risk of hypertension at the age of 40 years and above are 12 times greater than with age far under ah 40 years. The risk of hypertension at a young age is related to health-related lifestyles. ${ }^{0}$

An individual with history of hypertension on his/her family has the potential to suffer decreasing vagal function response that plays a role in regulating blood pres- sure. The chance of developing hypertension in someone with a family history, where only one parent has hypertension is $25 \%$, and if both parents are affected by hypertension, the chance is $60 \%{ }^{13,14}$ Based on the results of this study, it was found that the family history factor was significantly related to the prevalence of hypertension. Subjects with a family history of hypertension increase the risk of hypertension, four times, compared with subjects without a family history of hypertension. In line with this study, Kartikasari et al reported that the risk of hypertension was 14 times greater in individuals with a family history of hypertension. ${ }^{9}$ In another study, it was reported that the risk of developing hypertension in someone with family history, where only one parent suffered from hypertension, was $25 \%$. If both parents were suffered from hypertension, the chance of becoming hypertensive was $60 \%{ }^{13.14}$

Obesity is a risk factor of cardiometabolic disorders such as diabetes and hypertension. ${ }^{17}$ Obesity causes an increase of free fatty acids that increase the sensitivity of renin activity in the plasma leading to 
sodium retention ${ }^{5,18}$. This study found that cases with obesity (BMI $\geq 25 \mathrm{~kg} / \mathrm{m}^{2}$ ) increase the risk of hypertension 3 times higher than those with BMI $<25 \mathrm{kf} / \mathrm{m}^{2}$. This result is in line with Pradono and Junaidi who showed that cases with BMI $\geq 25 \mathrm{~kg} / \mathrm{m}^{2}$ have 2 times higher risk of hypertension compared to those with BMI $<25 \mathrm{Kg} / \mathrm{m}^{2}{ }^{2}{ }^{15}$ Hendy et al, reported that obese individuals with $\mathrm{BMI} \geq 25 \mathrm{~kg} / \mathrm{m}^{2}$ have 7 times higher risk of hypertension than individuals with $\mathrm{BMI}<25 \mathrm{Kg} / \mathrm{m}^{2} .{ }^{16}$

Smoking is identified by consuming $\geq 1$ cigarette per day for $\geq 1$ year. ${ }^{19}$ Smoking habit is one of the factors related to hypertension. ${ }^{19}$ Nicotine in cigarette can lead to hypertension by damaging endothelial lining of the blood vessel wall. ${ }^{10}$ We found that cases with a smoking habit of $\geq 20$ cigarettes per day have 3 times higher risk of hypertension compared to those who consume $<20$ cigarettes per day. Anggara dan Prayitno also found a similar result showing that people with smoking habit have 8 times higher risk of getting hypertension than those who do not have a smoking habit. ${ }^{10}$ Sugiharto reported that smoking habit increases the risk of hypertension by 2,4 times than without smoking habit. ${ }^{11}$ A study conducted by Narayana dan Sudhana showed that increasing systolic blood pressure by 10-25 $\mathrm{mmHg}$ and heartbeat by 5-20 times per minutes during smoking one cigarette. ${ }^{20}$ Another study from Bowman et.al conducted a longitudinal observation of 28,236 women for 9,8 years. Women who at the beginning have no hypertension had increased risk of hypertension after consuming 15 cigarettes per day. ${ }^{21}$

Excessive salt consumption can increase the risk of having cardiovascular disorders. ${ }^{22}$ The amount of salt intake needed to make an individual suffer from hypertension varies from each individual because of different levels of salt sensitivity. Recommended daily salt consumption is $\leq 6$ grams per day. ${ }^{23}$ This study found that cases with salt consumption $\geq 6$ grams per day have 2 times higher risk of hypertension compared to those who consume $<6$ grams of salt per day. Sugiharto reported that subjects with frequently consuming salty food ( $\geq 6$ gram) have 3,95 times higher risk of hypertension than those with less frequent salt consumption $\left(<6\right.$ gram). ${ }^{11}$ Increase the prevalence of hypertension by $15-20 \%$ was observed from consuming 5-15 gram of salt per day. ${ }^{9}$

The result of coffee consumption showed that coffee consumption is associated with the risk of hypertension. Individuals who drink coffee have 3 times higher risk of developing hypertension than those who do not drink coffee. The result showed an increased risk of hypertension 5 times higher at cases who drink $\geq 3$ cups of coffee per day compared to those who drink $<3$ cups of coffee per day. That finding is in line with a study conducted by Martiani dan Lelyana who reported that consuming 1-2 cups of coffee per day has 4 times higher risk of hypertension compared to not consuming coffee. ${ }^{24}$ There is no evidence yet of the amount of coffee associated with the risk of developing hypertension. However, drinking coffee containing 200-300 mg of caffeine or equal to 3-4 cups of coffee is associated with an increase in blood pressure. ${ }^{25}$

There are several weaknesses in this study because of the research design used and the number of samples. The casecontrol design used in this study often creates information bias, so the results obtained are often not in accordance with reality.

\section{CONCLUSION}

This study found that age, family history, BMI, smoking, high consumption of salt, and coffee consumption are significant risk factors for hypertension in subjects located in the Karangasem village, Karangasem regency, Bali.

\section{ACKNOWLEDGMENT}

We would like to thank all who had provided any assistance and support. Special thank and gratitude to Dr. I Ketut Tangking Widarsa, MPH, and dr. I Wayan Candera, MPH who had given us feedback and guidance during this study. We also 
would like to acknowledge primary health care (Puskesmas) of Karangasem village that helped to collect the data.

\section{REFERENCES}

1. Pradhan D. The Association Between SmokingandHypertensionin Ukraine. [Tesis]. Faculty of Health Sciences.University of Eastern Finland.2014. p:1-50.(Accessed: 2015, December 1st)

2. Kirtania K, Sultana N, Ahmed S and Khatun A. Association of Hypertension and Smoking with IschaemicStroke. Bangladesh J Med Biochem. 2010.3: 16-18.

3. Puavilai W, Laorugpongse D, Prompongsa S, et al. Prevalence and Some Important Risk Factors of Hypertension in Ban Paew District, Second Report. Journal of the Medical Association of Thailand. 2011; 94: 1069.

4. World Health Organization. A Global Brief on Hypertension: Silent Killer, Global Public Health Crisis. 2013.

5. Longo D, Fauci A, Kasper D, Hauser $\mathrm{S}$, Jameson $\mathrm{J}$ and Loscalzo J. Harrison's Principles of Internal Medicine, 18th Edition. McGraw-Hill Education, 2011.

6. Setyanda YOG, Sulastri D and Lestari Y. Hubungan Merokok dengan Kejadian Hipertensi pada Laki-Laki Usia 3565 Tahun di Kota Padang. Jurnal Kesehatan Andalas. 2015; 4.

7. Kementerian Kesehatan Republik Indonesia. Riset Kesehatan Dasar. Jakarta: Badan Penelitian dan Pengembangan Kesehatan Departemen Kesehatan Republik Indonesia. 2013.

8. Kementerian Kesehatan Republik Indonesia. Laporan Hasil Riset Kesehatan Dasar (RISKESDAS) Nasional 2007. Jakarta: Badan Litbangkes, Depkes RI. 2007.

9. Kartikasari AN, Chasani S and Ismail A. Faktor Risiko Hipertensi pada Masyarakat di Desa Kabongan Kidul, Kabupaten Rembang. [Skripsi]. Program Studi Pendidikan Dokter
Fakultas Kedokteran Universitas Diponegoro. 2012.

10. Anggara FHD and Prayitno N. FaktorFaktor yang Berhubungan dengan Tekanan Darah di Puskesmas Telaga Murni, Cikarang Barat Tahun 2012. Jurnal Ilmiah Kesehatan. 2013; 5: 205.

11. Sugiharto A. Faktor-Faktor Risiko Hipertensi Grade II Pada Masyarakat (Studi Kasus di Kabupaten Karanganyar). [Tesis]. Program Pascasarjana Universitas Diponegoro, 2007.

12. Anderson GH. Effect of Age on Hypertension: Analysis of Over 4,800 Referred Hypertensive Patients. Saudi Journal of Kidney Diseases and Transplantation. 1999; 10: 286.

13. Ota H, Furuhashi M, Ishimura S, et al. Elevation of Fatty Acid-Binding Protein 4 is Predisposed by Family History of Hypertension and Contributes to Blood Pressure Elevation. American journal of hypertension. 2012; 25: 1124-30.

14. Mannan H. Faktor Risiko Kejadian Hipertensi di Wilayah Kerja Puskesmas Bangkala Kabupaten Jeneponto Tahun 2012. 2013.

15. Pradono $\mathrm{J}$ and Junaidi $\mathrm{P}$. Pengaruh Faktor Komposisional dan Faktor Kontekstual Terhadap Kejadian Hipertensi di Jawa dan Bali. Media Penelitian dan Pengembangan Kesehatan. 2015; 25: 97-106.

16. Hendy $\mathrm{H}$, Lanang Sidiartha IG and Putu Nilawati GA. Obesityis Associated With Hypertensionin Adolescents. Medicina. 2013; 44.

17. Skinner AC, Perrin EM, Moss LA and Skelton JA. Cardiometabolic Risks and Severity of Obesity in Children and Young Adults. New England Journal of Medicine. 2015; 373: 1307-17.

18. Kotsis V, Stabouli S, Papakatsika S, Rizos Z and Parati G. Mechanisms of Obesity-Induced Hypertension. Hypertension Research. 2010; 33: 386-93.

19. 19. Li H, Tong W, Wang A, Lin $\mathrm{Z}$ and Zhang Y. Effects of Cigarette 


\section{WMJ (Warmadewa Medical Journal), Vol. 5 No. 1, Mei 2020, Hal. 29}

Smoking on Blood Pressure Stratified by BMI in Mongolian Population, China. Blood pressure. 2010; 19: 927.

20. Narayana I and Sudhana IW. Gambaran Kebiasaan Merokokdan Kejadian Hipertensi Pada Masyarakat Dewasadi Wilayah Kerja Puskesmas Pekutatan I Tahun 2013. E-Jurnal Medika Udayana. 2015; 4.

21. Bowman TS, Gaziano JM, Buring JE and Sesso HD. A Prospective Study of Cigarette Smoking and Risk of Incident Hypertension in Women. Journal of the American College of Cardiology. 2007; 50: 2085-92.

22. Mozaffarian D, Fahimi S, Singh GM, et al. Global Sodium Consumption and Death from Cardiovascular Causes. New England Journal of Medicine. 2014; 371: 624-34.

23. Fujita T. Mechanism of Salt-Sensitive Hypertension: Focus on Adrenal and Sympathetic Nervous Systems. Journal of the American Society of Nephrology. 2014; 25: 1148-55.

24. Martiani A and Lelyana R. Faktor Risiko Hipertensi Ditinjau Dari Kebiasaan
Minum Kopi (Studi Kasus Di Wilayah

Kerja Puskesmas Ungaran Pada Bulan Januari-Februari 2012). Program Studi Ilmu Gizi Fakultas Kedokteran Universitas Diponegoro. 2012.

25. Mesas AE, Leon-Muñoz LM, Rodriguez-Artalejo F and Lopez-Garcia E. The Effect of Coffee on Blood Pressure and Cardiovascular Disease in Hypertensive Individuals: ASystematic Review and Meta-Analysis. The American journal of clinical nutrition. 2011: ajcn. 016667.

26. Lee G and Schafer AI. Goldman's Cecil medicine. Twenty-Fourth Edition. 2012; 27: 375,1414

27. Lip GYH and Hall JE. Comprehensive Hypertension. Elsevier Health Sciences, 2007.

28. Komaling JK, Suba B and Wongkar D. Hubungan Mengonsumsi Alkoholdengan Kejadian Hipertensipada Laki-Lakidi Desa Tompasobaru II Kecamatan Tompasobaru Kabupaten Minahasa Sselatan. Jurnal Keperawatan. 2013; 1. 